\title{
ANALISIS PERSEPSI KONSUMEN DALAM MENYUSUN STRATEGI MENINGKATKAN KUALITAS PRODUK DI CAFE FEELTER
}

\author{
Lily Alia
}

Dr. Arianis Chan, S.IP., M.Si.

Cecep Safa'atul Barkah, S.Sos., M.AB., MBA.

Dr. Pratami Wulan Tresna, S.Sos., M.Si.

Jurusan Administrasi Bisnis Fakultas Ilmu Sosial dan Ilmu Politik, Universitas Padjadjaran cecep.barkah@unpad.ac.id

\begin{abstract}
This study was conducted to analyze consumer perceptions of prices, product quality and the atmosphere at the Feelter cafe. This research is a descriptive quantitative study with 65 respondents who had bought and came to the Feelter cafe but did not come back, and used judgmental sampling techniques. The results showed that based on the mean value, customer perceptions at Cafe Feelter on product quality were still not good. Based on the analysis of button two boxes, it can be seen that consumer perceptions of the quality of the product are not good because the majority of indicators show that they are dissatisfied rather than very satisfied.
\end{abstract}

Key Word : Perception, Quality Product

\begin{abstract}
Abstrak
Penelitian ini dilakukan untuk menganalisis persepsi konsumen terhadap harga, kualitas produk dan suasana di cafe Feelter. Penelitian ini merupakan penelitian kuantitatif deskriptif dengan 65 responden yang pernah membeli dan datang ke cafe Feelter akan tetapi tidak datang kembali, dan menggunakan teknik judgemental sampling. Hasil penelitian menunjukkan bahwa berdasarkan nilai mean, persepsi pelanggan di Cafe Feelter terhadap kualitas produk masih kurang baik. Berdasarkan analisis button two boxes dapat diketahui bahwa persepsi konsumen terhadap kualitas produk adalah kurang baik karena mayoritas indikator menunjukan tidak puas dibanding sangat puas.
\end{abstract}

Kata Kunci: Persepsi, Kualitas Produk.

\section{LATAR BELAKANG}

Dari waktu kewaktu bisnis dibidang makanan mempunyai kecenderungan terus meningkat, baik dari segi kuantitas maupun kualitasnya. Faktanya didasarkan pada kenyataan bahwa makanan merupakan kebutuhan pokok manusia. Hal ini sesuai dengan teori A.A Maslow, yang mendifinisikan bahwa sandang, pangan dan papan merupakan kebutuhan dasar manusia, atau ditingkatan kebutuhan paling dasar. Permintaan pangan yang terus meningkat karena merupakan kebutuhan dasar manusia berimbas terhadap peningkatan penawaran makanan. Hal ini sesuai dengan hukum permintaan dan penawaran (supply and demand law). Oleh karena itu, bisnis dibidang makanan juga selalu meningkat dan berkembang dari waktu kewaktu.

Dewasa ini, bisnis makanan melingkupi berbagai ragam, sebagai contoh adalah bisnis restoran dan bisnis popular catering (cafe, coffe shop, toko roti/ bakery dan steak house). Semakin banyaknya bisnis makanan yang berkembang, kususnya bisnis restoran, tidak semuanya mampu bertahan lama. Sebagian besar bisnis tersebut jatuh atau bangkrut karena beberapa faktor, antara lain faktor manajemen yang masih sederhana, kekurangan modal usaha dan hilangnya konsumen untuk mencari alternatif produsen lain.

Café berasal dari bahasa Perancis yang berarti minuman kopi. Namun seiring perkembangannya, cafe tidak hanya sebuah 
kedai yang menjual minuman kopi saja tetapi juga menjual beraneka macam makanan dan minuman. Keberadaan café seolah sudah menjamur dan dapat ditemui dimana-mana dengan berbagai konsep seperti cafe bergaya rumahan, bergaya klasik hingga bergaya modern. Makanan dan minuman yang ditawarkan pun beragam dari makanan ringan, makanan utama dan tentu saja berbagai macam olahan minuman yang sebagian besar berbahan dasar kopi.

Situasi sektor cafe/coffee shop di Indonesia dapat dikenali melalui tiga karakteristik. Pertama jenis usaha cafe/coffee shop yang tergantung pada jenis pelanggan tertentu, misalnya cafe yang mewah dan dikunjungi secara rutin oleh kelompok konsumen tertentu yang berpenghasilan tinggi. Kedua cafe/coffee shop yang dikunjungi oleh pelanggan tetap dengan interval kunjungan yang jarang frekuensinya. Berikutnya masyarakat Indonesia tidak mengenal budaya mengunjungi cafe/coffee shop, sisanya hanya mengenali sedikit, sedikit tertarik namun tidak mau mengkonsumsinya. Kelompok ini merupakan kelompok yang paling sulit untuk dijamah.

Maraknya bisnis kuliner mengharuskan para pelaku bisnis membuat usahanya tampil berbeda sehingga menarik minat konsumen untuk berkunjung dan dapat mempertahankan keberlangsungan usahanya. Salah satu cara untuk mencapai tujuan perusahaan adalah dengan mengetahui apa kebutuhan dan keinginan konsumen atau pasar sasaran serta memberikan kepuasan yang diharapkan oleh konsumen. Dalam hal ini strategi strategi pemasaran sangat berperan penting.

Feelter sendiri adalah Coffee Shop yang terletak tempat yang sangat strategis terdapat di dekat jalan provinsi yang memang sering dilalui kendaraan, tepatnya di jalan Kudang, Singaparna, Tasikmalaya. Sekitaran cafe Feelter ini dekat dengan gedung pemerintahan dan tidak jauh dari area pendidikan. Feelter ini memiliki slogan yaitu "Feelter Make You Feel
Better" dimana diharapkan konsumen yang datang ke cafe Feelter ini yang tadinya merasa penat menjadi santai dan nyaman. Untuk tema nya, Cafe Feelter ini mengangkat tema musik atau suasana musik, dimana musik itu bisa menjadi penenang disaat kita sedang tidak baik baik saja. Untuk interior sendiri, terdapat gambar gambar artis korea yang memang saat ini menjadi daya tarik kaum hawa, Feelter juga menyediakan alat musik untuk menjadi pendukung dari atmosfer yang diangkat dari cafe nya itu sendiri.

Berdasarkan pengamatan yang dilakukan oleh penulis bahwa cafe Feelter dalam segi tempat sudah dikatakan cukup untuk menarik perhatian para pembeli, dan banyaknya pembeli yang baru datang ke cafe Feelter ini. Dilihat dari pelayanan dan fasilitas yang ada di cafe feelter ini bisa dikatakan cukup baik dan cukup lengkap dan nyaman untuk dijadikan tempat santai. Akan tetapi pada kenyataanya sebagian besar dari pembeli baru yang datang, tidak datang kembali ke cafe Feelter ini. Hal ini menandakan ada satu variabel yang dirasa tidak cocok dengan orang orang atau konsumen yang datang ke Feelter ini. Dilihat dari latar belakang di atas, maka rumusan masalah dalam penelitian ini adalah: "faktor apa yang menyebabkan konsumen Feelter tidak dating kembal ke Cafe"

\section{TINJAUAN PUSTAKA Persepsi}

Persepsi sering kali digunakan dalam kehidupan sehari-hari. Akan tetapi arti dari persepsi itu sendiri menurut beberapa ahli, yang saya simpulkan secara sederhana merupakan setiap individu dalam kehidupan sehari hari akan menerima informasi, objek atau informasi yang berasal dari lingkungan sekitar, dimana informasi tersebut akan dimaknai oleh setiap individu, proses pemberian makna tersebut dinamakan persepsi. Berikut pengertian yang dikemukakan oleh beberapa ahli. 
Menurut Robins "perception is the process by which individuals select, organize, and interpret stimuli into a meaningful and coherent picture of the world. It can be described as "how we see the world around us." Two individuals may be exposed to the same stimuli, but how each person recognizes, selects, organizes, and interprets these stimuli is a highly individual process based on each person's own needs, values, and expectations." . Menurut Sarlito Wirawan Sarwono (1983:89), persepsi adalah kemampuan seseorang untuk mengorganisir suatu pengamatan, kemampuan tersebut antara lain: kemampuan untuk membedakan, kemampuan untuk mengelompokan dan kemampuan untuk memfokuskan. Oleh karena itu seseorang bisa saja memiliki persepsi yang berbeda beda, walaupun objek atau informasi yang didapat itu sama. Hal tersebut dimungkinkan adanya perbedaan dalam penilaian yang diberikan kepada suatu objek. Sedangkan menurut Leavit,1978 yang diambil dari Faradina, Triska (2007:8) persepsi memiliki pengertian dalam arti sempit dan arti luas. Dalam arti sempit persepsi yaitu penglihatan: bagaimana seseorang melihat sesuatu, dan dalam arti luas persepsi yaitu: pandangan atau pengertian, bagaimana seseorang memandang atau mengartikan sesuatu.

Sondang P. Siagian (1989) berpendapat bahwa persepsi merupakan suatu proses dimana seseorang mengorganisasikan dan menginterpretasikan kesan- kesan sensorisnya dalam usahanya memberikan suatu makna tertentu dalam lingkungannya. Indrajaya (1986) dalam Prasilika, Tiara H. (2007:10) berpendapat persepsi adalah proses dimana seseorang mengorganisasikan dalam pikirannya, memanfaatkan, mengalami, dan mengolah perbedaan atau segala sesuatu yang terjadi dalam lingkungannya.

\section{Kualitas Produk}

Produk yang dijual kepada konsumen dapat ditinjau berdasarkan kualitasnya. Kualitas mempunyai pengertian yang terus berkembang serta mengalami pergeseran makna dari waktu ke waktu. Pada awalnya kualitas adalah kesesuaian antara suatu standar yang ditetapkan, setelah itu tuntutan kualitas meningkat lagi menjadi kesesuaian dengan penggunaan, dalam arti walupuan sudah sesuai suatu standar tetapi pada akhirnya yang diukur adalah apakah produk tersebut dapat digunakan atau tidak. Dari sudut pandang pemasaran, kualitas berarti kemampuan produk untuk memuaskan kebutuhan atau keinginan pelanggan. Kualitas produk adalah satu dari salah satu alat yang paling sering digunakan oleh pemasar untuk melakukan positioning. Kualitas mempunyai imbas yang langsung terasa pada produk yang akan semakin mendekatkan pemasar dengan nilainilai pelanggan dan kepuasan pelanggan (Rangkuti, 2009, p.130).

Tuntutan dan kualitas terus berkembang dan semakin besar, di mana kualitas tidak terbatas hanya kepada penggunaan produk tersebut, tetapi berkembang ke arah bagaimana kebutuhan pelanggan secara eksplisit. Produk dikatakan berkualitas kalau produk tersebut sesuai dengan kebutuhan pelanggan secara eksplisit. Menurut Cannon, Perreault, dan McCarthy (2008, p.286) menyampaikan bahwa kualitas produk ditentukan oleh cara pelanggan memandang produk tersebut.

Dalam Robbins Kualitas produk terdapat 2 macam, diantaranya : 1 . Isyarat intrinsik adalah ciri fisik produk itu sendiri, seperti ukuran, warna, rasa, atau aroma. Dalam beberapa kasus, konsumen menggunakan karakteristik fisik (misalnya rasa es krim atau kue) untuk menilai kualitas produk. Konsumen suka percaya bahwa mereka mendasarkan evaluasi mereka terhadap produk kualitas pada isyarat intrinsik, karena itu memungkinkan mereka untuk membenarkan keputusan produk mereka (baik positif atau negatif) 
sebagai pilihan yang "rasional" atau "objektif". 2. isyarat ekstrinsik-Yaitu, karakteristik itu tidak melekat pada produk - menilai kualitas. Misalnya, meski banyak konsumen yang mengklaim mereka membeli suatu merek karena rasanya yang superior, mereka seringkali tidak dapat mengidentifikasi merek itu secara buta tes rasa.

\section{Suasana}

Sifat fisik lingkungan sebuah restoran kerap diacu sebagai store atmospheric. Sebagaimana disampaikan oleh Simamora (2003, p.279) yang menyatakan bahwa atmoster toko adalah keseluruhan efek emosional yang diciptakan oleh atribut fisik toko atau restoran tersebut. Sutisna (2001, p.164) mengatakan bahwa atmosfer adalah ruangan, baik yang di dalam ataupun di luar yang dapat memberikan kenyamanan kepada konsumen.

Cakupan strategi Store atmosphere bisa dikelompokan menjadi Instore dan Outstore. Store atmosphere bisa dipahami sebagai penataan ruang dalam (Instore) dan ruang luar (Outstore) yang dapat menciptakan kenyamanan bagi pelanggan. Menurut Levi dan Weitz (2001, pp.27-32), Store atmosphere terdiri dari dua hal, yaitu Instore atmosphere dan Outstore atmosphere.

1. Instore atmosphere Instore atmosphere adalah pengaturanpengaturan di dalam ruangan yang menyangkut:

a. Internal Layout merupakan pengaturan dari berbagai fasilitas dalam ruangan yang terdiri dari tata letak meja kursi pengunjung, tata letak meja kasir, dan tata letak lampu, pendingin ruangan, sound.

b. Suara merupakan keseluruhan alunan suara yang dihadirkan dalam ruangan untuk menciptakan kesan rileks yang terdiri dari live music yang disajikan restoran dan alunan suara musik dari sound system.

c. Bau merupakan aroma-aroma yang dihadirkan dalam ruangan untuk meniptakan selera makan yang timbul dari aroma makanan dan menuman dan aroma yang ditimbulkan oleh pewangi ruangan.

d. Tekstur merupakan tampilan fisik dari bahan-bahan yang digunakan untuk meja dan kursi dalam ruangan dan dinding ruangan.

e. Desain interior bangunan adalah penataan ruang-ruang dalam restoran kesesuaian meliputi kesesuaian luas ruang pengunjung dengan ruas jalan yang memberikan kenyamanan, desain bar counter, penataan meja, penataan lukisan-lukisan, dan sistem pencahayaan dalam ruangan.

2. Outstore atmosphere Outstore atmosphere adalah pengaturanpengaturan di luar ruangan yang menyangkut:

a. External Layout yaitu pengaturan tata letak berbagai fasilitas restoran di luar ruangan yang meliputi tata letak parkir pengunjung, tata letak papan nama, dan lokasi yang strategis.

b. Tekstur merupakan tampilan fisik dari bahan-bahan yang digunakan bangunan maupun fasilitas diluar ruangan yang meliputi tekstur dinding bangunan luar ruangan dan tekstur papan nama luar ruangan.

c. Desain eksterior bangunan merupakan penataan ruanganruangan luar restoran meliputi desain papan nama luar ruangan, penempatan pintu masuk, bentuk bangunan dilihat dari luar, dan sistem pencahayaan luar ruangan. 


\section{METODE PENELITIAN}

Penelitian ini menggunakan format penelitian deskripif, yaitu pengumpulan data untuk menjawab pertanyaan mengenai status terakhir dari subjek penelitian (Kuncoro, 2009, p.12). Populasi dalam penelitian ini adalah seluruh konsumen yang berkunjung ke Kafe Feelter namun tidak datang kembali. Jumlah konsumen yang berkunjung ke Feelter tidak menentu setiap bulannya. Berdasarkan perhitungan jumlah sampel dengan menggunakan populasi yang tidak teridentifikasi, maka didapatkan jumlah sampel dalam penelitian ini adalah sebanyak 45 orang. Teknik pemilihan sampel menggunakan judgmental sampling, yaitu pemilihan sampel dengan menggunakan pertimbangan tertentu (Istijanto, 2009, p.124). Pertimbangan yang digunakan adalah konsumen pernah berkunjung ke Feelter sebanyak 1 kali sehingga mengetahui kondisi Feelter. Data yang telah didapatkan kemudian dianalis menggunakan mean dan analisis Top To Boxes and Bottom To Boxes.

\section{HASIL PENELITIAN DAN PEMBAHASAN}

Responden Berdasarkan jumlah kuisioner yang layak dianalisis dan memenuhi persyaratan terdapat 45 responden dengan 16 laki-laki dan perempuan 29 orang dengan karakteristik yang terdapat pada tabel berikut.

Tabel 1

Karakteristik Responden

\begin{tabular}{|l|l|l|l|}
\hline Variabel & Kategori & Frekuensi & $\%$ \\
\hline \hline \multirow{4}{*}{ Jenis Kelamin } & Pria & 16 & 35,6 \\
\cline { 2 - 4 } & Wanita & 29 & 64,4 \\
\hline \multirow{4}{*}{ Usia } & $<15$ & 1 & 2,2 \\
\cline { 2 - 4 } & $15-25$ & 41 & 91,1 \\
\cline { 2 - 4 } & 25,35 & 3 & 6,7 \\
\cline { 2 - 4 } & $>35$ & 0 & 0 \\
\hline
\end{tabular}

Berdasarkan Tabel 1 dapat diketahui bahwa dari 45 orang konsumen Feelter yang menjadi sampel penelitian, dimana konsumen ini dengan jenis kelamin perempuan yaitu sebanyak 29 orang atau $64,4 \%$ dari total 45 orang responden. Pelanggan dengan usia antara 15-25 tahun adalah konsumen mayoritas pada Feelteryaitu sebanyak 41 orang $(91,1 \%)$ dari total responden, sedangkan konsumen dengan usia antara kurang dari 15 tahun adalah pelanggan minoritas pada Feelter Cafe yaitu sebanyak 1 orang $(2,2 \%)$ dari total keseluruhan responden dan usia lebih dari 35 tidak termasuk kedalam responden dalam penelitian ini dalam artian 0 dari total responden.

Deskripsi hasil dari hasil pengisian kuesioner yang dilakukan oleh responden terkait dengan harga dapat dirangkum dalam tabel berikut ini.

Tabel 2

Hasil Survey

\begin{tabular}{|l|l|l|l|l|l|l|}
\hline \multirow{2}{*}{ Variabel } & \multirow{2}{*}{ Kategori } & \multicolumn{6}{|l|}{ Penilaian } \\
\cline { 3 - 8 } & & 1 & 2 & 3 & 4 & 5 \\
\hline Harga & Harga & 0 & 3 & 30 & 9 & 3 \\
\hline \multirow{3}{*}{$\begin{array}{l}\text { Kualitas } \\
\text { Produk }\end{array}$} & Rasa & 0 & 1 & 25 & 19 & 0 \\
\cline { 2 - 8 } & Pelayanan & 0 & 1 & 21 & 17 & 6 \\
\cline { 2 - 7 } & $\begin{array}{l}\text { Varian } \\
\text { Makanan }\end{array}$ & 1 & 18 & 22 & 3 & 1 \\
\hline Suasana & Tema & 1 & 1 & 28 & 9 & 6 \\
\hline Promosi & Promosi & 0 & 2 & 29 & 10 & 4 \\
\hline
\end{tabular}

\section{Harga}

Tabel di atas menunjukkan bahwa dari variabel harga mayoritas sebanyak 30 responden dari 45 responden memilih angka 3 untuk Kepuasan konsumen terhadap harga yang telah ditetapkan oleh Cafe Feelter. Dapat dikatakan bahwa harga yang ditetapkan oleh Feelter ini sudah cukup baik bagi kantong konsumen.

Kualitas Produk

Dari hasil tabel diatas kategori Rasa mayoritas sebanyak 25 responden dari 45 responden memilih angka 3 untuk Kepuasan konsumen terhadap rasa 
makanan di Cafe Feelter. Akan tetapi bisa dilihati dari sisa responden sebanyak 19 orang menyatakan atau memilih angka 4 untuk rasa makanan yang ada di Feelter, jadi Dapat dikatakan bahwa rasa yang ditetapkan oleh Feelter ini sudah memuaskan untuk konsumen.

Kategori Pelayanan mayoritas sebanyak 21 responden dari 45 responden memilih angka 3 untuk Kepuasan konsumen terhadap pelayanan yang diberikan oleh Cafe Feelter. 17 responden memilih angka 4 dan 6 orang memilih angka 5 dimana angka 5 merupakan sangat memuaskan. Jadi Dapat dikatakan bahwa pelayanan yang diberikan oleh feelter mayoritas konsumen sudah merasa baik atau memuaskan.

Kategori Varian Makanan mayoritas sebanyak 22 responden dari 45 responden memilih angka 3 untuk Kepuasan konsumen terhadap varian makanan yang ada oleh Cafe Feelter. Akan tetapi sebanyak 18 responden memilih angka 2, dan 1 responden memilih angka 1 , dimana angka 1 dan 2 terdapat di penilaian kurang memuaskan bagi konsumen. Jadi Dapat dikatakan bahwa varian makanan yang ada di Feelter ini masih kurang baik atau kurang memuaskan.

\section{Suasana}

Dari tabel diatas terdapat penilaian terhadap suasana di cafe feelter, yaitu sebanyak 28 responden dari total 45 responden memilih angka 3,9 responden memilih angka 4 dan 6 responden memilih angka 5. Dapat disimpulkan bahwa suasana yang diciptakan oleh Feelter cukup memaskan untuk konsumen karena tidak ada penilaian yang buruk pada variabel suasana.

\section{Promosi}

Dari tabel diatas terdapat penilaian terhadap suasana di cafe feelter, yaitu sebanyak 28 responden dari total 45 responden memilih angka 3,9 responden memilih angka 4 dan 6 responden memilih angka 5. Dapat disimpulkan bahwa suasana yang diciptakan oleh Feelter cukup memaskan untuk konsumen karena tidak ada penilaian yang buruk pada variabel suasana.

Top Two Boxes dan Bottom Two Boxes Analisa Top 2 Boxes dan Bottom 2 Boxes adalah analisis yang dilakukan untuk mengkategorisasikan jawaban responden. Top adalah jawaban responden setuju dan sangat setuju, sementara bottom adalah jawaban responden yang tidak puas dan sangat tidak puas.

Tabel 3

\begin{tabular}{|l|l|l|l|l|}
\hline Variabel & Kategori & Buttom & Netral & Top \\
\hline Harga & Harga & 3 & 30 & 12 \\
\hline \multirow{2}{*}{$\begin{array}{l}\text { Kualitas } \\
\text { Produk }\end{array}$} & Rasa & 1 & 25 & 19 \\
\cline { 2 - 5 } & Pelayanan & 1 & 21 & 23 \\
\cline { 2 - 5 } & $\begin{array}{l}\text { Varian } \\
\text { Makanan }\end{array}$ & 19 & 22 & 4 \\
\hline Suasana & Tema & 2 & 28 & 15 \\
\hline Promosi & Promosi & 2 & 29 & 14 \\
\hline
\end{tabular}

Pada tabel 3 dapat dilihat tingkat kesetujuan responden terhadap setiap item pertanyaan pada setiap variabel. Terjadi perbedaan yang cukup signifikan pada item varian makanan. Kategori variasi makanan mayoritas responden setuju bahwa variasi makanan di Feelter kurang memuaskan, dapat dilihat dari Button Box sebanyak 19 responden dimana menunjukan konsumen tidak puas atau sangat tidak puas.

\section{Formulai Strategi Pemasaran}

Cafee Feelter merupakan bisnis starup yang memang baru didirikan bberapa bulan, Sumber daya keuangan Feelter ini hanya berasal dari modal pemiliknya. Pendapatan yang diperoleh Feelter berasal dari penjualan makanan/minuman yang ada di café tersebut, dan beberapa pengeluaran yang perlu ditanggung oleh Feelter seperti membayar sewa bangunan, biaya gaji, dan lain sebagainya. 
Café Feelter ini berlokasi Jl.Kudang Kec. Singaparna Kab. Tasikmalaya. Café ini cukup luas dan memiliki 2 tempat untuk dijadikan took yaitu di dalam ruangan dan di luar ruangan, akan tetapi lahan parker yang cukup sempit jika dibendingkan dengan luas lahan café nya itu sendiri. Lokasi Feelter ini berada di lokasi strategis karena berada di pinggir jalan provinsi dan di kelilingi oleh insansi pendidikan dan instansi pemerintahan. Namun lokasi ini juuga bisa menjadi ancaman menjadi Feelter sendiri, karena banyaknya competitor café shop yang serupa di lokasi tersebut.

Tidak dapat dipungkiri bahwa sekarnag ini adalah era digital, sehingga dapat dikatakan hamper semua aktivitas berkaitan dengan digital dan teknologi serta aktivitas bisnis. Feeelter dala menjual produk memanfaatkan too offline dan online seperti instagram dan facebook. Dan juga sudah masuk dan daftar ke grabfood dan go-food. Saat ini Feelter memiliki 5 orang karyawan. Dimana karyawn di feelter memiliki nilai sikap yang diterapkan yaitu ramah, humble, jujur, dan bertanggunng jawab.

\section{Usulan Strategi Pemasaran}

Berdasarkan analisis hasil survey yang telah saya lakukan, saya merumuskan strategi dalam menarik konsumen yang tidak dating kembali ke café yang dilakukan oleh Feelter. Bentuk strategi diarahkan ke ppeningkatan kualitas produk di Feelter itu sendiri diantaranya :

1. Menambah varian makanan

Dilihat dari lingkungan yang bberdekatan dengan café feelter ini banyak juga café yang serupa. Dengan adanya varian makanan yang lebih beragam, bisa menjadi daya Tarik konsumen untuk datang kembali ke cafe

2. Memperbagus dalam kemasan yang diberikan

Disini penjual tidak hanya menjual rasa dalam makanan akan tetapi menjual bagaimana penampilan produk, agar tingkat pembelian dan value-added yang ditawarkan bisa tampak dari kemasan dan semuanya tambak bernilai

3. Menerapkan level pelayanan

Selain tempat usaha dan tempat penjualan dpat juga menngkatkan tingkat level pelayannan, penjual juga dapat membedakan tingkat level pelayanan untuk pembelian produk ukuran tertentu, atau untuk frekuensi pembelian tertentu. Misalnya tempat usaha bisa membuat tiga paket layanan : Paket POP, Paket Dangdut, Paket Jazz kepada para pelanggan atau pembeli

4. Memberikan penghargaan kepada pelanggan tertentu dan juga hadiah

Sebagai penjual dapat memberikan semacam penghargaan kepada pelanggan yang sangan dengan baik mengenal atau mahir menggunakan dan menikmati produk anda, atau pembeli besar yang setia. Penghargaan yang dimaksud adalahmembuat mereka merasa menjadi pelanggan yang istimewa.

\section{KESIMPULAN DAN SARAN}

Berdasarkan analisis data dan pembahasan yang telah dilakukan sebelumnya, dapat diambil kesimpulan sebagai berikut:

1. Persepsi terhadap harga Persepsi pelanggan terhadap harga di Feelter sudah cukup baik. Hal ini ditunjukkan dengan banyaknya jumlah responden sebanyak 30 responden dari 45 responden memilih angka 3 untuk kepuasan harga, sehingga semamng lebih baik mengadakan promosi atau strategi harga yang harus dilakukan oleh feelter.

2. Persepsi terhadap kualitas produk, pada kategori rasa makanan sebanyak 25 responden dari 45 responden memilih angka 3 untuk Kepuasan konsumen terhadap rasa makanan di Cafe Feelter. Akan tetapi bisa dilihati dari sisa responden sebanyak 19 orang menyatakan atau memilih angka 4 untuk rasa makanan yang ada di Feelter, jadi Dapat dikatakan bahwa rasa yang ditetapkan oleh Feelter ini sudah memuaskan untuk konsumen. 
3. Kategori Pelayanan mayoritas sebanyak 21 responden dari 45 responden memilih angka 3 untuk Kepuasan konsumen terhadap pelayanan yang diberikan oleh Cafe Feelter. 17 responden memilih angka 4 dan 6 orang memilih angka 5 dimana angka 5 merupakan sangat memuaskan. Jadi Dapat dikatakan bahwa pelayanan yang diberikan oleh feelter mayoritas konsumen sudah merasa baik atau memuaskan.

4. Kategori Varian Makanan mayoritas sebanyak 22 responden dari 45 responden memilih angka 3 untuk Kepuasan konsumen terhadap varian makanan yang ada oleh Cafe Feelter. Akan tetapi sebanyak 18 responden memilih angka 2, dan 1 responden memilih angka 1 , dimana angka 1 dan 2 terdapat di penilaian kurang memuaskan bagi konsumen. Jadi Dapat dikatakan bahwa varian makanan yang ada di Feelter ini masih kurang baik atau kurang memuaskan. Dan bisa kita simpulkan variabel kualitas produk pada kategori varian makananlah yang menjadikan konsumen tidak datang kembali ke cafe Feelter.

5. Kategori suasana di cafe feelter, yaitu sebanyak 28 responden dari total 45 responden memilih angka 3, 9 responden memilih angka 4 dan 6 responden memilih angka 5. Dapat disimpulkan bahwa suasana yang diciptakan oleh Feelter cukup memaskan untuk konsumen karena tidak ada penilaian yang buruk pada variabel suasana.

6. Kategori suasana di cafe feelter, yaitu sebanyak 28 responden dari total 45 responden memilih angka 3, 9 responden memilih angka 4 dan 6 responden memilih angka 5. Dapat disimpulkan bahwa suasana yang diciptakan oleh Feelter cukup memaskan untuk konsumen karena tidak ada penilaian yang buruk pada variabel suasana.
Dari kesimpulan yang diambil, dapat diberikan beberapa saran sebagai berikut:

1. Pihak perusahaan hendaknya melakukan perbaikan terhadap aspek harga, kualitas produk, dan suasana dengan cara:

a. Melakukan penambahan varian produk yang dijual dengan harga yang lebih bervariasi. Varian dapat dapat dilakukan dengan cara mengurangi porsi makanan yang akan berdampak pada harga yang lebih murah sehingga lebih terjangkau.

b. Meningkatkan nilai estetika dalam penyajian makanan sehingga penyajian makanan menjadi lebih menarik. Dibuat variasi cara penyajian sehingga pelanggan tidak merasa bosan dengan cara penyajian makanan.

c. Menambah menu makanan dan minuman yang ada di cafe

d. Menjadikan suasana di cafe Feelter menjadi lebih nyaman dan atraktif sehingga akan tetap mampu menarik pelanggan meskipun area parkir yang terdia cukup sempit di banding luas cafe itu sendiri.

2. Pihak perusahaan perlu memberikan perhatian khusus kepada aspek kualitas produk karena aspek ini adalah aspek yang mendapatkan penilaian paling rendah dari responden.

3. Perlu dilakukan analisis terhadap persepsi konsumen Feelter secara berkelanjutan agar pihak perusahaan juga dapat melakukan perbaikan secara berkelanjutan.

\section{DAFTAR PUSTAKA}

Schiffman G. Leon \& Wisenblit L. Joseph. 2015. Consumer Behavior, eleventh edition. England: Pearson Education

Sugiyono. 2011. Metode Penelitian Kuantitatif Kualitatif dan R\&D. Bandung : Alfabeta

Irawan, Christianto, and Michael Loekito. "Analisa Pengaruh Marketing Mix (7p) Terhadap Keputusan Pembelian Di Folks! Coffee Shop and Tea Housesurabaya." Jurnal Hospitality dan Manajemen Jasa, vol. 2, no. 1, 2014, pp. 86-100. 
Winata, A. S., \& Gienardy, R. (2013). Analisa Persepsi Konsumen Terhadap Harga, Kualitas Produk, Dan Suasanan Di Cafe My Kopi O. Jurnal Hospitality dan Manajemen Jasa, 1(2), 529-537.

Joel, G., Massie, J. D., \& Sepang, J. L. (2014). Pengaruh Motivasi, Persepsi Harga, Dan Kualitas Produk Terhadap Minat Beli Konsumen Sepeda Motor Matic Merek Yamaha Mio Di Kota Manado. Jurnal EMBA: Jurnal Riset Ekonomi, Manajemen, Bisnis dan Akuntansi, 2(3).

Wicaksosno, A. (2019). Analisis

Pengaruh Bauran Pemasaran Jasa Terhadap Sale Pada Hotel Galuh Anindita Yogyakarta. Khasanah Ilmu-Jurnal Pariwisata Dan Budaya, 10(2), 91-97.

Thio, S. (2012). Persepsi

Konsumen Terhadap Makanan Organik Di Surabaya. Jurnal Manajemen Perhotelan, 4(1), 18-27.

Lauw, J. (2013). Analisa Pengaruh Kualitas Layanan Terhadap Kepuasan Pelanggan Di The Light Cup Cafe Surabaya Town Square Dan The Square Surabaya. Jurnal Strategi

Pemasaran, 1(1).

Susanti, C. E. (2003). Analisis Persepsi Konsumen terhadap Kualitas Produk Keramik Merek Milan di Surabaya. Widya Journal of Management and Accounting, 3(2), 220048.
Suharto, G. P. (2017). Pengaruh Gaya Hidup, Suasana Toko dan Kualitas Pelayanan terhadap Keputusan Pembelian pada Giggle Box Café \& Resto Semarang. Jurnal Ilmu Administrasi Bisnis, 6(1), 118 129.

Andriani, D. (2020). Pengaruh Kualitas Pelayanan Dan Suasana Resto Terhadap Keputusan Pembelian Pada Café And Resto Sugar Rush Di Bontang. Administrasi Bisnis, 8(1), 27.

Pitriani, W. A. (2019). PENGARUH PERSEPSI HARGA, KUALITAS PELAYANAN DAN SUASANA CAFE TERHADAP KEPUTUSAN PEMBELIAN (Studi Pada Konsumen Geprek King Bandar Lampung).

Saidani, B., \& Arifin, S. (2012). Pengaruh kualitas produk dan kualitas layanan terhadap kepuasan konsumen dan minat beli pada ranch market. JRMSIJurnal Riset Manajemen Sains Indonesia, 3(1), 1-22.

Hidayat, R. (2009). Pengaruh kualitas layanan, kualitas produk dan nilai nasabah terhadap kepuasan dan loyalitas nasabah Bank Mandiri. Jurnal Manajemen dan kewirausahaan, 11(1), 59-72.

Putro, S. W. (2014). Pengaruh Kualitas Layanan dan Kualitas Produk Terhadap Kepuasan Pelanggan dan Loyalitas Konsumen Restoran Happy Garden. Jurnal Strategi Pemasaran, 2(1), 19. 